Arendt and Heidegger 



\section{Arendt and Heidegger}

THE FATE OF THE POLITICAL

- DANA R. VILla •

P R I N C E T O N U N I V E R S I T Y P R E S S

P R I N C E T O N, NE W J E R S E Y 
Copyright (C) 1996 by Princeton University Press

Published by Princeton University Press, 41 William Street, Princeton, New Jersey 08540

In the United Kingdom: Princeton University Press, Chichester, West Sussex

All Rights Reserved

Library of Congress Cataloging-in-Publication Data

Villa, Dana Richard.

Arendt and Heidegger : the fate of the political / Dana R. Villa.

p. cm.

Includes bibliographical references and index.

eISBN 1-4008-0828-6

1. Arendt, Hannah-Contributions in political science.

2. Heidegger, Martin, 1889-1976-Contributions in political science.

3. Political science-Philosophy. I. Title.

JC251.A74V55 1995.

$320^{\prime} .092^{\prime} 2-\mathrm{dc} 20 \quad 95-13293$

This book has been composed in Goudy 
- TO MY PARENTS •

A L F R E D V I L L A A N D

V I R G I N I A B A R R E T T V I L L A 
